EESTI NSV TEADUSTE AKADEEMIA TOIMETISED, 27. KÖIDE

KEEMIA. 1978, NR. 4

ХИМИЯ. 1978, № 4

ИЗВЕСТИЯ АКАДЕМИИ НАУК ЭСТОНСКОИ ССР. ТОМ 27

Г. РАЯЛО, Т. ВОЛЕНС, Тийа САВИЧ, Р. ТЯХТ

удК $541.124: 128$

\title{
КИНЕТИКА ГИДРОХЛОРИРОВАНИЯ ДИМЕТИЛБУТАДИЕНА
}

Присоединение хлористого водорода к жидким алкадиенам находит применение в ряде новых технологических процессов производства полимеров, душистых веществ, витаминов, инсектицидов и других продуктов, имеющих большое значение для народного хозяйства. В наших предыдущих статьях $\left[{ }^{1,2}\right]$ рассматривались механизм и кинетика реакций присоединения хлористого водорода к изопрену и пиперилену. В литературе пока отсутствуют данные о механизме и кинетике гидрохлорирования диметилбутадиена.

Рассмотрим жидкофазную реакцию присоединения хлористого водорода к диметилбутадиену без присутствия растворителя и катализатора, т. е. в реагирующей системе находятся хлористый водород, диметилбутадиен, образовавшиеся гидрохлориды и промежуточные комплексы.

При гидрохлорировании диметилбутадиена образуется смесь из 1,2и 1,4-аддуктов по следующей суммарной реакции:

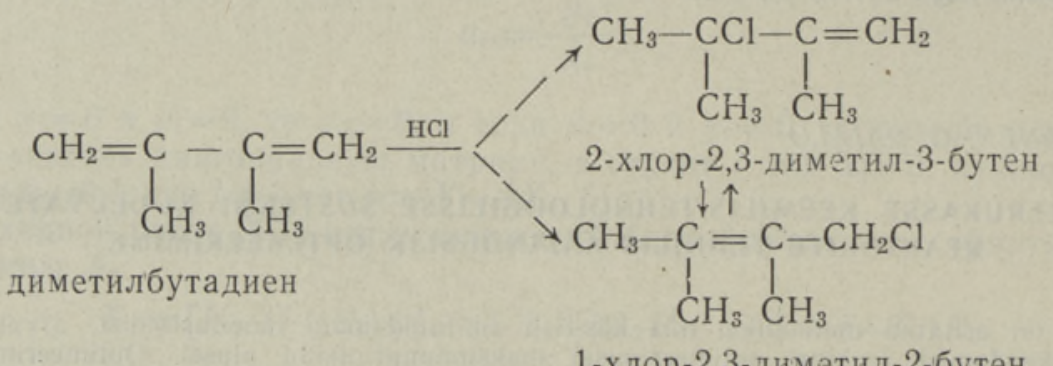

1-хлор-2,3-диметил-2-бутен

Изучить кинетику образования 1,2- и 1,4-аддуктов в отдельности трудно, поскольку одновременно с образованием обоих изомеров происходит их взаимная изомеризация. Продукт гидрохлорирования диметилбутадиена содержит обычно 50-70\% 1-хлор-2,3-диметил-2-бутена и $30-50 \%$ 2-хлор-2,3-диметил-3-бутена. При этом, по нашим наблюдениям, содержание 1,2-аддукта в свежеприготовленном продукте выше, чем в этом продукте после длительного хранения. Кинетика гидрохлорирования рассматривается нами только с точки зрения суммарного образования гидрохлоридов.

Опыты по изучению кинетики гидрохлорирования диметилбутадиена проводились в стеклянном лабораторном реакторе периодического действия при стационарном изотермическом режиме. При этом применялась 
в основном та же методика, что и в случае изучения кинетики гидрохлорирования изопрена и пиперилена $[1,2]$. Опыты проводились при темпеpaтурах $50,35,20$ и $0^{\circ} \mathrm{C}$ : при каждой температуре - 4 опыта с разными начальными концентрациями диметилбутадиена и его гидрохлоридов в исходной смеси. Исходное соотношение этих компонентов варьировалось от $1: 3$ до. $10: 1$ по весу. Компоненты для изготовления исходных смесей были очищены ректификацией. Пробы отбирались на $0,15,30,45,75$, $105,165,225,345,465,585$-ой минутах до достижения степени превращения $\sim 95 \%$, для чего требовалось $5-12$ ч. Пробы в объеме 1 c. ${ }^{3}$ для определения аналитического содержания хлористого водорода быстро вводили в $10 \mathrm{~cm}^{3}$ сухого ацетона и титровали 0,1 н. раствором триэтиламина в бензоле. Индикатором служил $0,1 \%$ раствор бромфенолсинего в ацетоне. Содержание диметилбутадиена и его гидрохлоридов в реакционной смеси до и после опытов определялось методом газовой хроматографии.

Экспериментальные данные по гидрохлорированию диметилбутадиена хорошо аппроксимируются кинетическим уравнением, соответствующим механизму реакции, установленному нами, как наиболее вероятному, в случае гидрохлорирования изопрена и пиперилена $\left[{ }^{1,2}\right]$. Этот механизм, учитывающий образование промежуточного молекулярного комплекса между диметилбутадиеном и хлористым водородом, а также присоединение хлоридиона к молекуле хлористого водорода, дает суммарное кинетическое уравнение в виде:

$$
\frac{d x}{d \tau}=\frac{k_{1}\left(a_{1}-x\right)^{2}\left(a_{2}-x\right)}{\left[k_{2}\left(a_{2}-x\right)+1\right]^{2}} .
$$

Здесь $x$ - количество прореагировавшего вещества в $\kappa м о л ь / \mu^{3}, \tau-$ время в сек, $a_{1}$ - исходная аналитическая концентрация хлористого водорода в $\kappa м о л ь / \mu^{3}, a_{2}$ - исходная аналитическая концентрация диметилбутадиена в кмоль/. $\mu^{3}$.

Предполагаем, что входящие в вышеприведенное уравнение константы скорости реакции зависят от температуры в К по закону Аррениуса $k_{1}=A_{1} \cdot \mathrm{e}^{-B_{1} / T}$ и $k_{2}=A_{2} \cdot \mathrm{e}^{-B_{2} / T}$. Нами определены числовые значения коэффициентов $A_{1}, A_{2}, B_{1}, B_{2}$, максимально соответствующие результатам опытных данных.

Одновременный поиск наиболее подходящих значений всех четырех кинетических коэффициентов проводился минимизацией суммы абсолютных значений относительных от́клонений всех наших экспериментальных данных от расчетных, полученных интегрированием вышеприведенного кинетического уравнения при разных начальных концентрациях компонентов. Поиск минимума проводился по модифицированному градиентному методу с переменными масштабными множителями [$\left.{ }^{3}\right]$ на ЭВM.

В результате вычислений получены числовые значения коэффициентов с приближенными доверительными границами, установленными с $95 \%$-ной вероятностью: $A_{1}=136 \pm 38, \quad A_{2}=3,86 \pm 0,75, \quad B_{1}=2680 \pm 99$ и $B_{2}=603 \pm 37$.

Заменяя кинетические константы в вышеприведенном уравнении найденными нами их температурными зависимостями, получаем следующее сводное выражение скорости реакции гидрохлорирования диметилбутадиена:

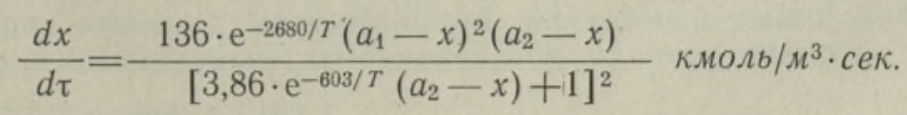


ЛИТЕРАТ У Р А

1. Р а яло Г., Са вич Т., Дементьев а В., Аннус А., Л ээтс К. Кицеетика гидрохлорирования изопрена. - Изв. АН ЭССР, Хим. Геол., 1970, т. 19, № 4, c. $309-316$.

2. Р аяло Г., Демен тьева В., Т яхт Р., Кудрявцев И., Л ээтс К. Кинетика гидрохлорирования пиперилена. - Изв. АН ЭССР, Хим. Геол., 1972, т. 21, № 4, c. $310-313$.

3. Т я х т Р., Р а я л о Г. Модифицированный градиентный метод определения констант химической кинетики. Таллин, Ин-т химии АН ЭССР, препринт 3, 1975.

Ннститут химии

Академии наук Эстонской ССР

\section{Поступила в редакцию} 24/XI 1977

G. RAJALO, T. VOLENS, Tiia SAVIC, R. TÄHT

\section{DIMETUULBUTADIEENI HUDROKLOREERIMISE KINEETIKA}

Artiklis on käsitletud vesinikkloriidi ja dimetüülbutadieeni liitumist isotermilises perioodilise töörežiimiga reaktoris. On kirjeldatud selle vedelafaasilise homogeense reaktsiooni miehhanismi ja kineetikat ning esitatud kineetiliste konstantide arvväärtused.

G. RAJALO, T. VOLENS, Tiia SAVICH, R. TÄHT

\section{KINETICS OF HYDROCHLORINATION OF DIMETHYLBUTADIENE}

An investigation of the liquid-phase homogeneous reaction of addition of hydrogen chloride to dimethylbutadiene is reported. The experiments have been carried out in an isothermal batch reactor. The reaction mechanism and the values of the rate constants are presented. 